\title{
The extent of historic translocation of Norway spruce forest reproductive material in Europe
}

\author{
Simon Jansen $^{1} \cdot$ Heino Konrad ${ }^{1}$ - Thomas Geburek ${ }^{1}$
}

Received: 14 September 2016 / Accepted: 9 May 2017 / Published online: 13 July 2017

(C) INRA and Springer-Verlag France 2017

\begin{abstract}
- Key message Norway spruce seed has been traded extensively for at least three centuries throughout the natural distribution range in Europe and beyond. However, our knowledge about these transfers is limited. Historic data are essential tools to trace back human-mediated gene flow and for interpretation of recent genetic studies.

- Context Human-mediated gene flow can potentially have a major impact on the genetic composition of forest tree populations, yet our knowledge about seed sources used within the current species' range is still limited. Norway spruce is one of the most important coniferous species in European forestry, and data drawing conclusions about the genetic composition of current populations are vital with regard to gene conservation and sustainable forest management. Because molecular
\end{abstract}

Handling Editor: Bruno Fady

Contribution of the co-authors Simon Jansen: writing the manuscript and running the data analysis.

Heino Konrad: coordinating the research project, supervising and writing the manuscript.

Thomas Geburek: supervising and writing the manuscript.

Electronic supplementary material The online version of this article (doi:10.1007/s13595-017-0644-z) contains supplementary material, which is available to authorized users.

Thomas Geburek

thomas.geburek@bfw.gv.at

Simon Jansen

simon.jansen@bfw.gv.at

Heino Konrad

heino.konrad@bfw.gv.at

1 Department of Forest Genetics, Austrian Research Centre for Forests (BFW), 1131 Vienna, Vienna, Austria data are not available on a more detailed scale, historic records provide crucial information about translocations.

- Aims Our aim is to provide the first pan-European review on Norway spruce translocations from the seventeenth until the twentieth century.

- Methods We analysed historic and recent literature compiling information on the cultivation and transfer of Norway spruce reproductive material. Historic records are compared with recent molecular studies.

- Results Seed exchanges have profoundly altered the native genetic population structure of Norway spruce. Especially, Central European seeds have been used throughout and beyond the natural distribution area. Figures illustrating the historic plantings in Europe are provided.

- Conclusion Recent molecular data reveal persisting effects of past translocations. Historical records can be extremely useful for providing information about autochthony and thus guide gene conservation strategies and explain the performance of extant populations.

Keywords Picea abies · Afforestation · Historic seed transfer $\cdot$ Seed trade

\section{Introduction}

Within the last decades, the protection and conservation of nature and biodiversity has become an important issue on the European political agenda. Forest ecosystems have been identified as a major source of biodiversity (FAO 2014), and the biocentric view recognizing "naturalness" of forests as an intrinsic value has been strengthened (EEA 2014). As genetic diversity is a central part of biodiversity, factors impacting the gene pool of European forest populations need to be scrutinized (e.g. Geburek and Turok 2005; Graudal et al. 2014; 
Koskela and Lefèvre 2013; Koskela et al. 2007; Wickneswari et al. 2014). Throughout the last three centuries, European forests experienced fundamental changes and the genetic composition of most of today's tree populations have been strongly affected by man (EEA 2014). Starting in the eighteenth century, artificial regeneration with non-local seeds became common practice, including the transfer of conifers such as Norway spruce on a large scale (e.g. Endres 1905; Koskela et al. 2014; Schmidt-Vogt 1977; see also Table 1). Seeds from Central Europe (Germany, Austria) became a particularly cherished commodity (e.g. Almäng 1996; Dering 2008; Lines 1987).

Norway spruce (Picea abies [L.] Karst.) is one of the most important tree species in Central and Northern Europe, due to its high ecological plasticity and economic versatility (Schmidt-Vogt 1977). Its range is differentiated into three distinct areas: (a) Alpine, (b) Hercyno-Carpathian and (c) BalticNordic region (Fig. 1). During the last three centuries, the distribution of Norway spruce has been significantly enlarged by cultivation (Schmidt-Vogt 1977; Spiecker 2003). Today, P. abies covers an area of approximately $30,000,000$ ha in Europe; more than $20 \%$ of the current distribution is located outside its native range, primarily growing on former broadleaved forest sites at low altitude (Klimo et al. 2000). In some countries, such as Germany, France or Poland, the artificial range vastly exceeds the native occurrence (Jansson et al. 2013). In the majority of cases, unknown seed sources were used for these afforestations. Although this humanmediated gene flow must have had a significant impact on Norway spruce populations, our knowledge about historic transfer is still very limited (e.g. Geburek 2005).

The specific origin of spruce provenances at a given site cannot be identified by phenotypic characteristics, although the crown architecture (Geburek et al. 2008) or colour of immature cones (Geburek et al. 2007) may provide clues about an elevational transfer. Molecular data (e.g. Tollesfrud et al. 2008) can serve as a valuable baseline to study the historic transfer of forest reproductive material (FRM); however, highresolution data are not available throughout the current distribution range of Norway spruce.

Local adaptation of Norway spruce is mainly determined by the growing period: early flushing and early growth cessation are characteristics of northern or high-altitude provenances when translocated to lower altitude or southern sites (Gomöry et al. 2012; Jansson et al. 2013). These provenances generally grow slowly in lower elevations or southern regions (Giertych 2007), while a northward transfer or a movement to higher elevations results in higher growth rates in most cases (e.g. Frank et al. 2017; König 2005). However, in the latter case, plants are threatened by damage from early frost (Jansson et al. 2013). An altitudinal transfer of about $200 \mathrm{~m}$ or a $6^{\circ}$ northward transfer of seed sources from Central Europe is nevertheless possible without ecological or economic risks (Bergmann 1965; Giertych 2007; König 2005; Konôpka and Šimak 1990). The translocation of Romanian provenances by $12^{\circ}$ of latitude has been suggested, while a movement of Alpine provenances outside the Alps is generally not recommended (König 2005). Within Scandinavia, a northward transfer should be limited to $3^{\circ}$ latitude (Bergmann 1965; Giertych 2007). Provenances which thrive well under very different ecological conditions originate from the Eastern Carpathians, Bihor Mountains, and the mountainous region extending from the Beskides and the Ore Mountains to the foothills of the Harz (Budeanu et al. 2012; König 2005; Matras 2009).

The objective of this study is to review historic records of Norway spruce translocations. These findings are of special importance, as genetic data tracking the original seed source are presently not available on a European scale. Historic records can help to identify translocation "hotspots" or areas comprising putative autochthonous populations, which is of special interest for tree breeding or gene conservation (e.g. Rajora and Mosseler 2001; Spiecker 2000). The disclosure of FRM trading routes is vital for interpreting results from recent molecular studies. Data about historic seed transfer may also contribute to the understanding of intraspecific variation patterns, as proposed by Gomöry et al. (2012). The importance of the integration of historic aspects for assessment of forest genetic resources in Europe has also been pointed out by several other authors (Laikre et al. 2006; Schoppa 2000; Ledig 1992).

\section{Methods}

An extensive literature survey was conducted comprising a wide variety of historic and recent literatures, including journal articles and grey literature, as well as the compilation of data about cultivations and the transfer of Norway spruce FRM. This survey was conducted in the scope of the EUfunded project FORGER (Towards the sustainable management of forest genetic resources) between 2014 and 2016. We examined web databases of academic journals, as well as library catalogues. Keywords (artificial regeneration, cultivation, forestation, kiln, Norway spruce, seed production and seed trade) in German, English, French, Czech, Polish and Romanian databases were used to identify relevant articles. We tried to minimize the language bias in the survey by involving also local colleagues to identify relevant literature. Advertisements of seed trading companies can provide further clues on used seed sources and trading areas; as digitizing of older issues of journals frequently skipped advertisements, print copies of forestal periodicals were used as information sources whenever possible. As several archives are not accessible or have been destroyed (such as the entire documentation of seed trading companies near Darmstadt; Bendix 2008), the 


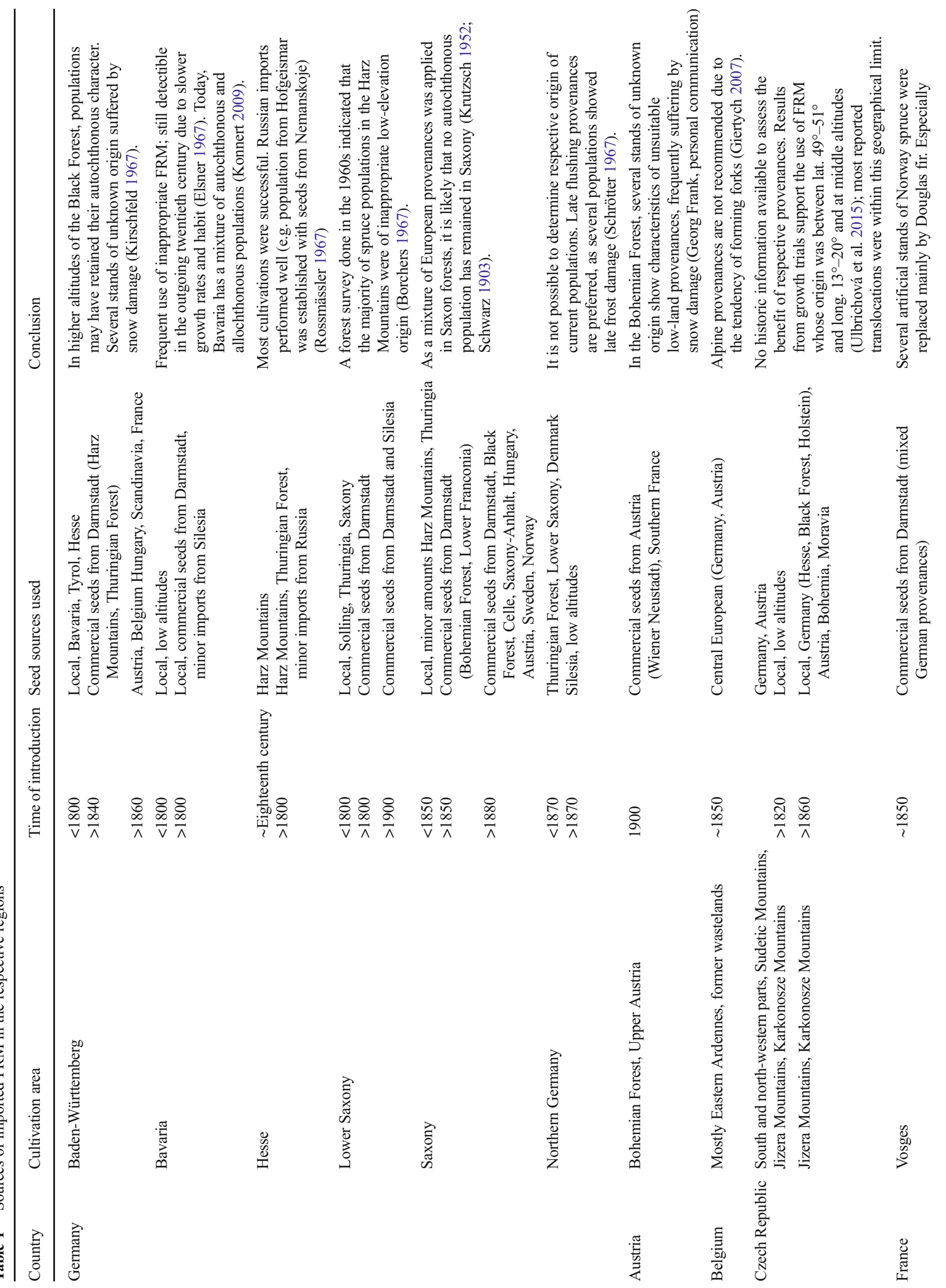




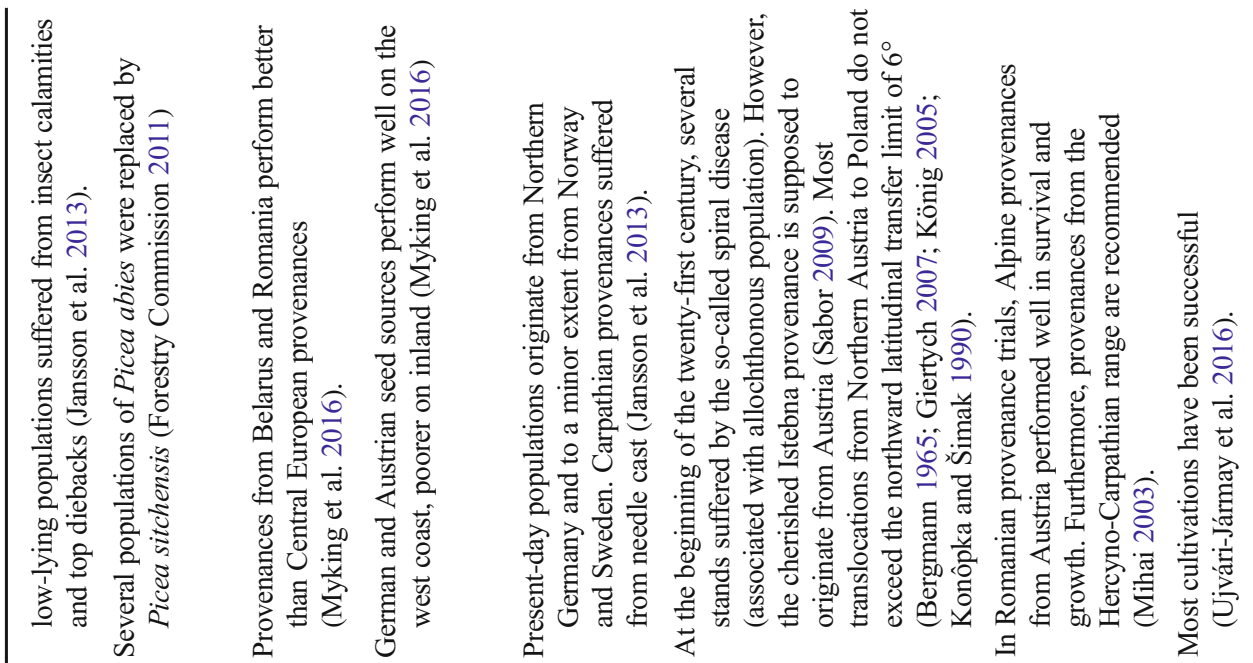

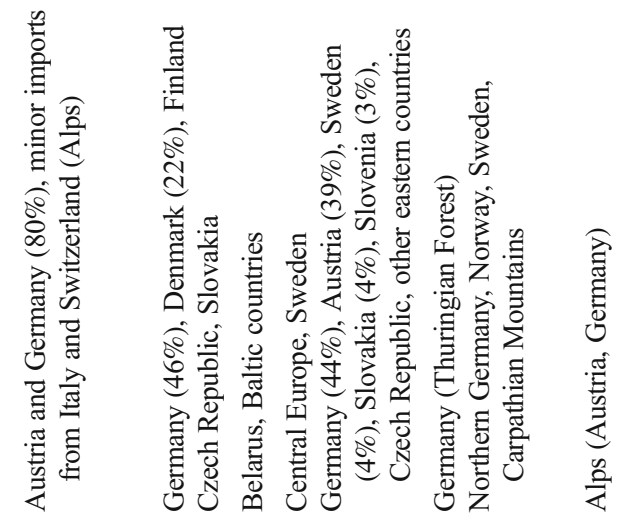

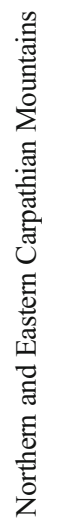

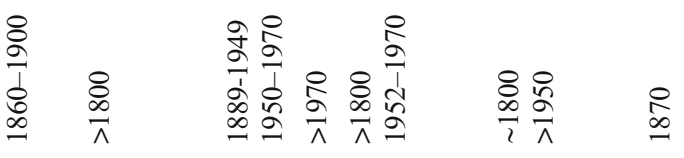

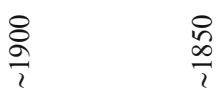

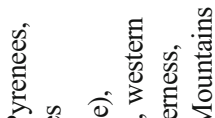

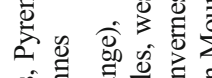

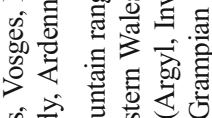

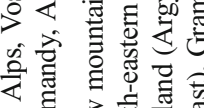

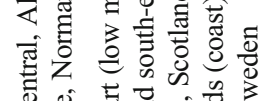

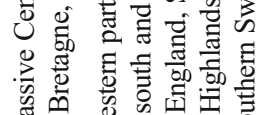

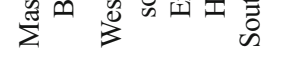

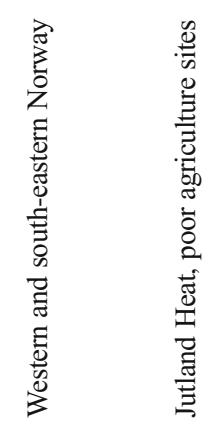

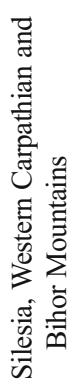

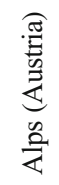

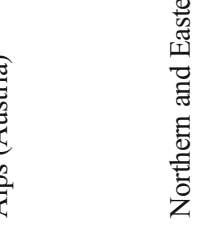

总

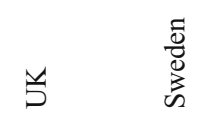

ᄅे

䓂

픙

:

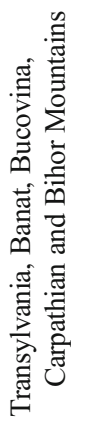


Fig. 1 Cultivations of Norway spruce in Europe until 1800

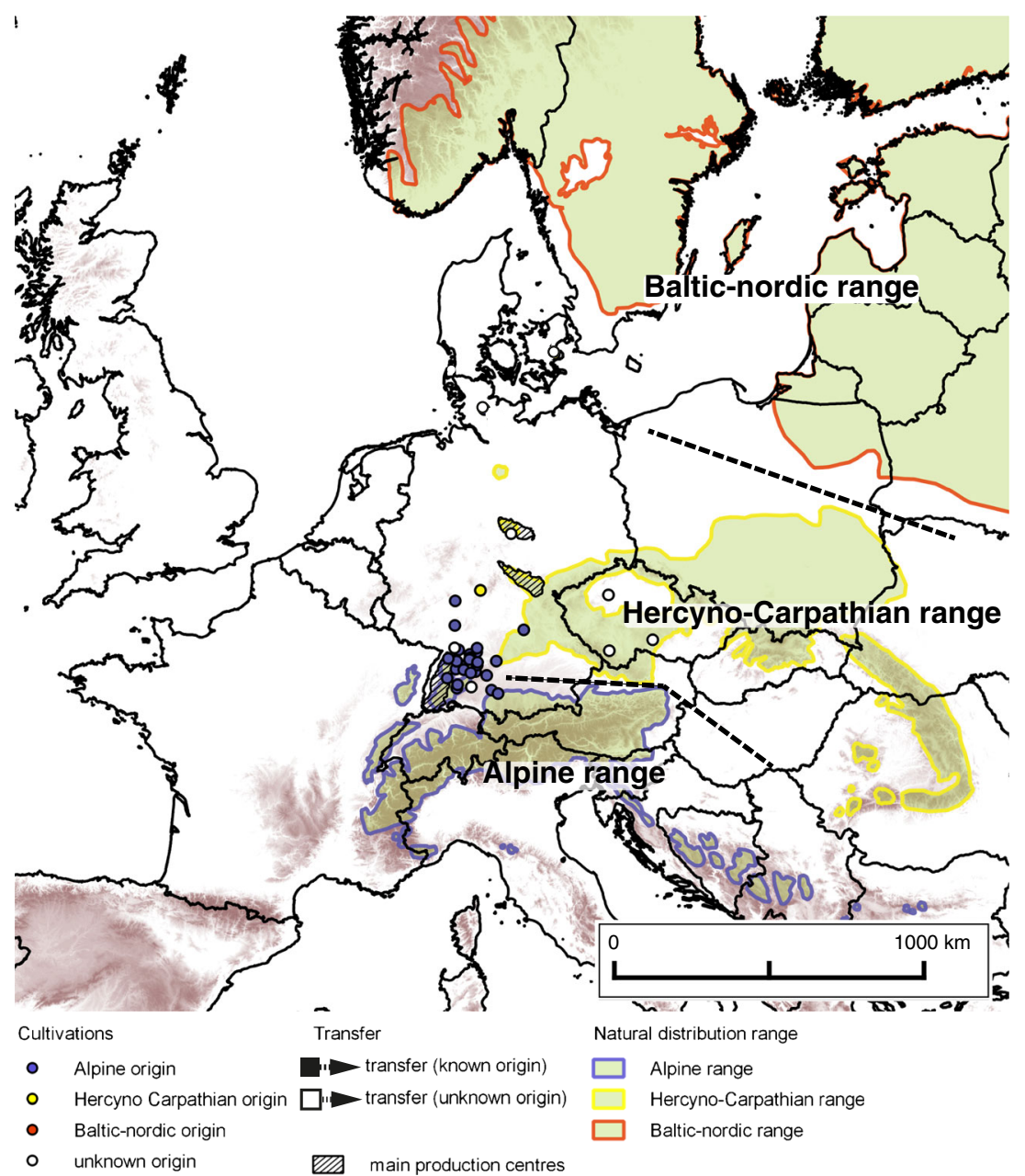

remaining historic literature is vital to expose humanmediated translocations. Unfortunately, during the literature survey, it became evident that the exact origins, as well as the amount of transferred material, were very rarely recorded. As forest management often differed at the regional level, former historic links between regions or political entities were also considered for tracking historic trading routes (e.g. Habsburg Monarchy). Information about seed traders and their respective production areas were also important data to reveal putative seed sources (e.g. Volk 1969).

Most articles were published at the turn of the twentieth century, when the importance of provenances became increasingly recognized in forestry. The thus obtained referenced historic data were stored in a database with information about the cultivation place, cultivation year, putative seed source, and the respective reference (Online Resource Table 1). Overall 1784 records were referenced. In many cases geographical locations of cultivations had to be determined by the toponym or were geo-referenced using historic maps. The presented Figs. 1, 2 and 3 illustrate the respective cultivations and transfers throughout the observed period; each dot represents a literature reference. Arrows illustrate additional transfers, where geographical data of cultivation places were missing. The natural distribution range is based on SchmidtVogt (1977). To examine the persistent impact of historic translocations, we compared our results with recent genetic analyses. The geographic distribution of characteristic haplotypes is based on data given in Tollefsrud et al. (2008), supplemented by Mengl et al. (2009) and Konrad et al. (2011).

\section{Results and discussion}

The history of European forests is closely linked with human activities. Long-standing overexploitation shaped the forests not only in stand structure and tree composition but also in their gene pool (e.g. Myking et al. 2016; Nowakowska 2009). At the end of the seventeenth century, the forests of most European countries were devastated and substantially cleared (for review, see Bradshaw 2004; Kaplan et al. 2009). By the eighteenth century, reforestation started throughout Europe. The conversion of coppice into high forests arose from a growing timber demand following the industrial revolution. Fast growing conifers such as Norway spruce were favoured 
Fig. 2 Cultivations of Norway spruce in Europe until 1900

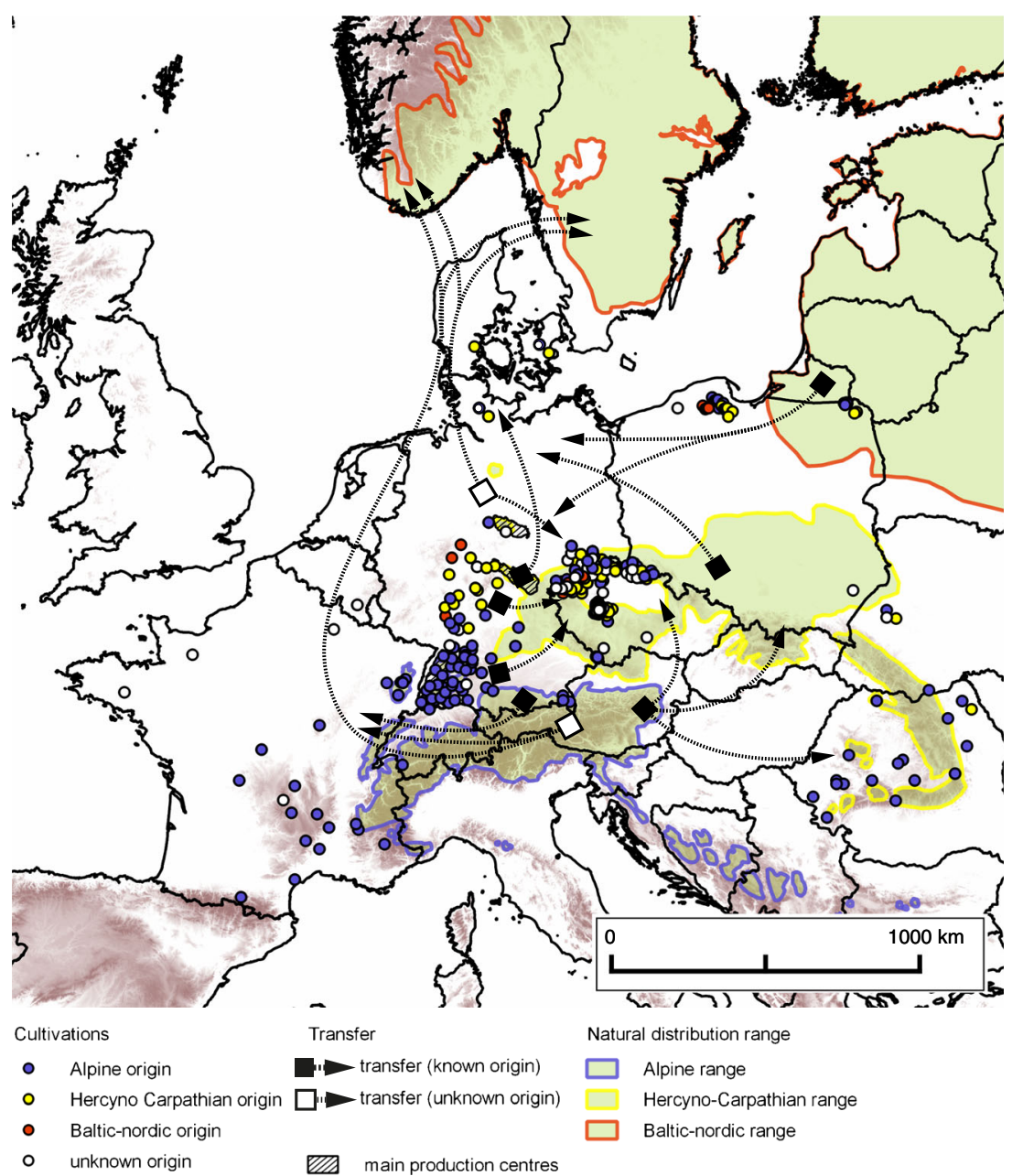

(e.g. Hornstein 1958; Klimo et al. 2000). Unavailability of local seed sources innervated the commerce with FRM, and leading trading centres for Norway spruce seeds were established especially in Germany (Black and Thuringian Forest, region around the city of Darmstadt) and Austria. Seed sources traded varied, and the genetic differentiation of FRM originating from different elevational levels was frequently neglected (e.g. Bouvarel 1965).

\subsection{Regional cultivation and translocations of Norway spruce-Central Europe}

The first cultivations of spruce occurred in Germany as early as the sixteenth century (Haack 1909; Hornstein 1958; Immel 1933; Köhler 1952), but gained significant momentum much later - at the beginning of the eighteenth century (Borcher 1967; Volk 1969). During that time, present-day Germany consisted of several sovereign microstates which often differed in their forestry regulations. Therefore, it is not surprising that the use of FRM varied even on a small regional scale, e.g. in today's German state of Baden-Württemberg. This region was separated into three historic states (County of Hohenzollern, Grand Duchy of Baden, Kingdom of Württemberg), among which the transfer of spruce FRM differed considerably (see also Online Resource Fig. 1). Local seeds were predominantly used in Württemberg, but provenances from the Northern Black Forest were also transported to the SwabianFranconian Forest, Palatinate and Baden (Volk 1969). No information exists about spruce provenances used in Hohenzollern, but imports from Württemberg are likely (Volk 1969). Until the early nineteenth century, Baden purchased seeds only from Württemberg, but gradually increased imports from Bavaria, Tyrol and the landgraviate of Hesse-Darmstadt. From 1840, the majority of spruce seeds were obtained from traders located in Darmstadt, where most likely provenances from the Harz Mountains and Thuringian Forest were traded (Volk 1969). However, 20 years later, commercial FRM became also common in Württemberg, and huge amounts of seeds originating from the Harz Mountains, the Black and Thuringian Forest as well as from Austria, Belgium, Hungary, Scandinavia, and France were introduced to the forests of present-day Baden-Württemberg (e.g. Volk 1969; Zimmermann 1931). 
Fig. 3 Cultivations of Norway spruce in Europe until 1950

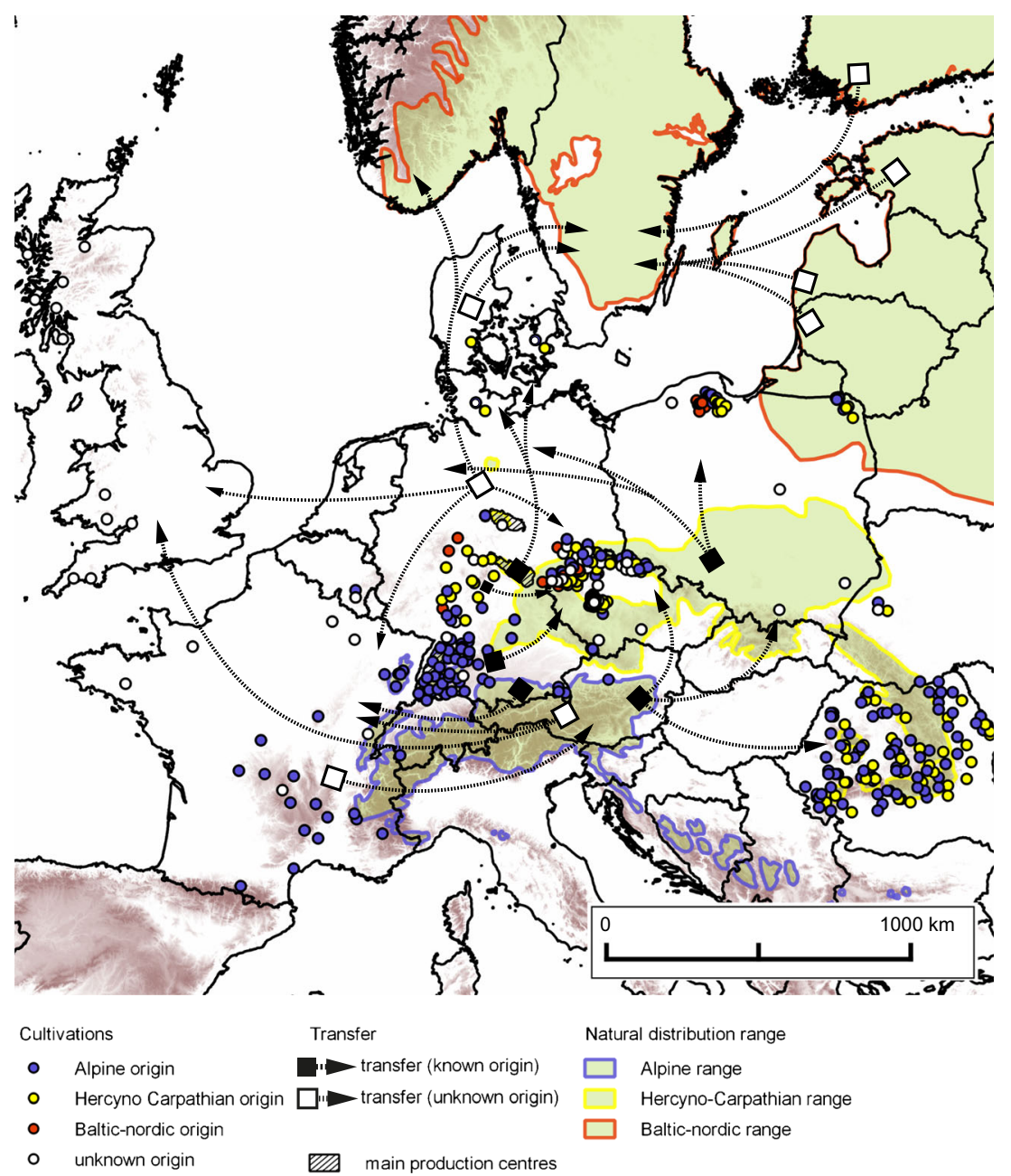

In Bavaria, especially in the south-eastern high-altitudinal exploitation region (Berchtesgadener Alps), afforestations with non-local FRM became common. Until the end of the eighteenth century, predominantly, Bavarian seeds from lower altitudes were used (Elsner 1967; Rohmeder 1972). However, with the nineteenth century, commercial seed suppliers were increasingly favoured. For instance, in the district Ruhpolding, approximately $7000 \mathrm{~kg}$ of seeds and 800,000 spruce plants from commercial seed traders were employed between 1852 and 1863 . Nearly $85 \%$ of the regeneration area was cultivated with plants of putatively unsuitable provenances (Zierhut 2003). From 1870 to 1876, many Bavarian spruce populations were destroyed by wind and insect calamities and huge amounts of FRM were obtained from various seed traders in the Darmstadt region (e.g. Dingethal 1970; Hausrath 1908) and to a lesser extent from Silesia (Ruetz and Bergmann 1989).

In Hesse, spruce was primarily introduced to the Vogelsberg area and the Forest of Odes (Rossmässler 1967). Most cultivations were successful and consequently a forest regulation in 1741 specifically recommended the use of
Norway spruce. Such success was probably due to FRM which had been predominantly obtained from the Harz Mountains. At the beginning of the nineteenth century, the species was widely spread and several cultivations, such as the well-known spruce provenance "Waldeck" were established by the middle of the century (Fig. 2). Due to proximity and strong political ties, the use of seeds from the Thuringian Forest is likely (e.g. Kappes 1972; Rossmässler 1967). Further imports have also been reported from northeastern Europe. For instance, the well-known population from Hofgeismar was established with seeds from Nemanskoje (East Prussia; today part of Russia) (Rossmässler 1967).

In Lower Saxony, FRM was probably obtained from local populations from the western foothills of the Harz Mountains (Borchers 1967), Solling, Thuringia and Saxony (Kremser 1990). In the nineteenth century, the distribution of Norway spruce further increased, e.g. in the "Westerhof" district of the Harz Mountains, where the proportion of spruce increased from zero to $82 \%$. Huge amounts of seeds were obtained from Darmstadt seed traders. At the beginning of the twentieth century, seed imports from Silesia were also reported (Fig. 3). A 
forest survey done in the 1960s indicated that the majority of spruce populations in the Harz Mountains were of inappropriate low-elevation origin which frequently suffered from snow damage (Borchers 1967).

Seed sources used in Saxony until the mid-nineteenth century were mainly local. However, occasionally, FRM was imported from the Harz Mountains and Thuringia. During the second half of the nineteenth century, several imports from Southern Germany (Bohemian Forest, Lower Franconia) were reported (Krutzsch 1952; Zimmermann 1931). Furthermore, seeds were provided by seed traders from Darmstadt between 1865 and 1889. More details are available for the period between 1880 and 1910, when seeds from Thuringia, the Harz Mountains, Black Forest, Celle, Lower Franconia, SaxonyAnhalt, Hungary, Southern Austria, Sweden and Norway were introduced to Saxony (Zimmermann 1931). Moreover, FRM was used from the community of Halstenbek (Northern Germany, see below), which already was at that time a production centre for forest seedlings (Krutzsch 1952). In conclusion, a mixture of European provenances was applied in Saxon forests, and it is likely that no autochthonous population has remained in Saxony (Krutzsch 1952; Schwarz 1903).

Norway spruce is not native in Northern Germany, and seed transfer from the Thuringian Forest (Schwarz 1903), Lower Saxony and North Zealand (Denmark) (e.g. Fuhrmann 1926; Schrötter 1967) was reported. From 1870, Prussia became a major provider of spruce seeds and probably mostly supplied Silesian provenances from low altitudes (e.g. Schrötter 1967) (Fig. 2).

In Austria, large-scale monocultures of spruce were established, especially in the mountainous range of the Alps and in the Bohemian Forest (Hornstein 1958). In the Bohemian Forest, FRM was predominantly obtained from kilns and seed traders from the city of Wiener Neustadt (Lower Austria) (Rachoy 1971). However, poor growth performance and high level of insect damages indicated the use of unsuitable seed sources (Schmidt-Vogt 1977). It is noteworthy that in this area, molecular data also indicate a high proportion of allochthonous populations (Geburek et al. 2016). Also, in Upper Austria, many sites afforested with Norway spruce failed between 1916 and 1923 (Hornstein 1958; SchmidtVogt 1977). Tulstrup (1959) reported that at the beginning of the twentieth century, large quantities of spruce seeds were exported from Southern France to Austria (Fig. 3). Therefore, the mixing of foreign and local seeds is likely during that period. An area of about 384,000 ha was restocked during and after World War II (Schmidt-Vogt 1977). Specific seed sources were not recorded. However, a survey in the Bohemian Forest gives evidence for the use of a high proportion of non-local FRM sources (Georg Frank, personal communication).

Data on the cultivation area and seed sources used in Germany and Austria after Wold War II are barely available.
However, reports in forestry journals and the records of forest enterprises producing local FRM (e.g. Rausch 1949) indicate the use of mixed provenances. For instance, in Bavaria, nearly 100,000 ha had to be restocked, whereof the share of Norway spruce was high. While in the Bavarian state forests (about $50 \%$ of clear-cut area) predominantly local provenances were used, the origin of seeds used in private forest remains unknown (Rubner 1954).

\subsection{Western Europe}

Norway spruce naturally covers the Western Alps, the Jura Mountains and a limited area in the Vosges Mountains (Bouvarel 1965; Vogel-Daniels 1968; Woolsey 1920). Since the mid-nineteenth century, this tree species has been introduced to Belgium, Luxembourg and France (e.g. Mullin et al. 2011, Schmidt-Vogt 1977). In Belgium, the first plantings of Norway spruce were recorded at higher altitudes of the Eastern Ardennes (Duterme 1962). It was a favoured tree species for afforesting former wastelands and was soon introduced also to the western part of the country (Duterme 1962; Schmidt-Vogt 1977). By the middle of the twentieth century, over 143,000 ha had been established exclusively with seeds from Central Europe, mostly from Germany and Austria (Gathy 1960).

Norway spruce was mainly spread in France from the nineteenth century (Pourtet 1952) and by the middle of the twentieth century about 250,000 ha of spruce forest had been established outside the native range (Marcu 1980; SchmidtVogt 1977). Early cultivations in the Vosges Mountains were of unknown origin (Oberdorfer 1937; Schmidt-Vogt 1977). However, seed supplies from traders based in Darmstadt were frequently reported and indicate the use of admixed German provenances (Berard 1959; Fuhrmann 1926). Until the midnineteenth century, cultivations were small scale and mainly limited to lower altitudes. Two cultivation waves implementing governmental regulations of 1860 (Loi sur la Reboisement des Montagnes) and 1862 (Loi sur la Restauration des Montagnes) followed (Vogel-Daniels 1968). Between 1860 and 1900, more than 1 million ha were afforested with Norway spruce, European larch, Scots and Black pine in France (Pourtet 1952). P. abies was introduced on a large scale to the Massive Central (Puy-de-Dôme, Cantal, Creuse, Haute Vienne, Haute Loire, Lozére, Herault, Ardéche, Gard), the Alps (Luc-en-Diois, Arrondissement of Die, Col de Labouret), the Vosges Mountains and the Pyrenees (Bartoli 2003; Brown 1880; Gadant 1968; Vogel-Daniels 1968) (Fig. 2). Scattered cultivations were also established in north-western France (Bretagne, Normandy) and in the Ardennes (Duterme 1962). The extensive use of foreign provenances is likely since productive kilns were not available in France during that time (Noël 1882). Additionally, affordable prices and high availability of commercial seeds also favoured 
the import of allochthonous FRM, even if local seed sources were available (Bouvarel 1958). Large amounts of seeds were obtained from Austria and the Alsace (Noël 1882), and, e.g. between 1853 and 1884, nearly $5000 \mathrm{~kg}$ per year was imported from Bavaria and Austria (Bartoli and DemesureMusch 2003) (Fig. 2). Between the two world wars, the forest cover decreased and considerable efforts to use $P$. abies were made in the Plateau Lédonien (Jura) and the "zone rouge" in Verdun (Pardé 1965; Vogel-Daniels 1968). The second peak of spruce cultivation commenced after World War II leading to a total area of 250,000 ha by the middle of the twentieth century (Schmidt-Vogt 1977). The production of local FRM was insufficient and about $50 \%$ of the used seeds were introduced from other countries, again without any indication about their origin (Pourtet 1946). Since non-local FRM was predominantly used at the margins of the native range of $P$. abies, an alteration of the native gene pool can be expected.

In Great Britain, spruce cultivation started mainly in the nineteenth century (Lines 1987), peaking in the 1920s (Fig. 3). During that time, Norway spruce was the most important tree species for artificial regeneration, mainly planted at low mountain ranges in the western part of the island. In 1979, Norway spruce covered an area of about 116,850 ha (Lines 1987). Large-scale cultivations were performed at wind protected slopes of the Brecon Beacons Mountains (southeastern Wales), the Cambrian Mountain (Southern Wales), the Forest of Dean (western England) or along river valleys at lower altitude. In the south of England, the tree species is abundant in the downs of Dartmoore and Bodmin Moor. In Scotland, the largest cultivations were found along the fiords and lakes in Argyll (Firth of Clyde, Loch Awe) and Inverness. Within the Highlands, the planting was concentrated on the coastal regions. Smaller cultivations were reported for the Grampian Mountains and the islands Mull and Skye (Schmidt-Vogt 1977). According to Lines (1987), more than $80 \%$ of introduced seeds originated from Austria and Germany, followed by minor imports from the Italian and Swiss Alps.

\subsection{Eastern Europe}

First cultivations of Norway spruce are already known in this region since the seventeenth century, such as in the Central and North-western Czech Republic (near Jihlava and Budyñ) (Nožička 1967, 1972). However, the main cultivation wave started during the nineteenth century (Fig. 2). Large areas were cultivated with Norway spruce in south- and northwestern Czechia (Jeleček 1973; Nožička 1972), for instance, along the Sudetic and Karkonosze Mountains (Modrzyński 1989). Information about seed sources is limited, but studies in the Bohemian Forests, Křivoklát Mountains (Central Bohemia), Krkonoše Mountains and Jizera Mountains reflect the anthropogenic impact on Norway spruce populations
(Blahá undated; Lokvenc 1989; Svoboda 1943; Šnytr 2009). Sowing of Norway spruce in the Jizera Mountains started around 1820 and was initially performed with local provenances, mostly from low altitudes (Šnytr 2009). Since the 1860s, the use of allochthonous FRM increased steadily. Besides provenances from the northern and north-eastern Czech Republic (Zákupy, Oskava, Svéborice), seeds from Germany (Hesse, the Black Forest, historic region of Holstein), Poland (Upper Lusatia) and unknown sources were used (Šnytr 2009). In the Bohemian Forests, along the ridgeline of Tř́stoličník, Trojmezná and Plechý, nearly two thirds of the forests were replaced by Norway spruce, and the area of spruce more than doubled its natural occurrence. Although no detailed records exist, Blahá (undated) mentioned the use of Alpine seed sources. This is also in line with Svoboda (1943) who stated seed imports from German and Austrian traders for Central Bohemia (Křivoklát). While first cultivations in the Krkonoše Mountains were performed strictly with local material, from the $1860 \mathrm{~s}$, more and more seeds were obtained from commercial seed traders due to attractive pricing and high seed quality (Lokvenc 1989). Cultivations were primarily performed up to $1000 \mathrm{~m}$ a.s.l. and different proportions of foreign seed sources were reported (Matuszkiewicz and Matuszkiewicz 1960). Seeds were purchased by seed traders from Southern Germany, Austria and the Czech Republic (Lokvenc 1989). German traders supplied mainly FRM originating from Swabia and Hesse, Austrian companies traded Northern Alpine seed sources and the seeds originating from today's Czech Republic were a mixture of Bohemian and Moravian provenances (Turnov, České, Budějovice) (Lokvenc 1989). The influence of imported material along the Krkonoše Mountains was immense. Between 1887 and 1920 , nearly $17,000 \mathrm{~kg}$ of spruce seeds was traded. For instance, in Vrchlabí (Southern Krkonoše Mountains), approximately $96 \%$ of the used seeds between 1850 and 1920 were of non-local origin. In general, Lokvenc (1989) estimated the proportion of allochthonous populations in the Krkonoše Mountains of about 40\% (Lokvenc 1989). By the middle of the twentieth century, nearly 2,000,000 ha in the Czech Republic were planted with Norway spruce and Scots pine (Fig. 3). The amount of spruce reached 55\%, whereof the native share was only $11 \%$ (Blahá, undated). The vulnerability of these artificial populations was already known in the early twentieth century, but the discussion about the use of allochthonous seeds did not start earlier than after World War II (Klimo 1992). Nearly $50 \%$ of the spruce forests found outside the natural distribution area in the third or even fourth generation are of unknown seed origin (Mansfeld 2011).

Most spruce afforestations in Slovakia - for instance, in the region of Kysuce (Northern Slovakia)—were established with admixed FRM between 1750 and the middle of the twentieth century. According to Kulla (2011), local provenances and seed sources from Germany, Austria and Bohemia were 
employed. Several diebacks at low altitudes of the Tatra, Orava, Zipser Magura or the Ore Mountains indicate the use of unsuitable provenances (Kmet et al. 2010). In Hungary, Norway spruce was introduced in the middle of the nineteenth century, and current populations originate most likely from seed sources from the Northern and Eastern Carpathians (Ujvári-Jármay et al. 2016).

In Poland, the cultivation of Norway spruce began in the last third of the nineteenth century in Silesia (Porabka), the Western Carpathians and the Beskids (e.g. Dering 2008). Again, detailed information about the use of foreign seeds are not at hand, but the influence of German and Austrian forestry during the 19th and twentieth century was significant (e.g. Bardecki 1909; Dering 2008). For instance, Western Galicia (today Southern Poland) was part of the Austrian Empire and several afforestations were performed by Austrian foresters using Alpine seed sources (Bałut 1962; Fuhrmann 1926). Moreover, during that period, the most advanced kiln in the Austrian-Hungarian Empire was located in Wiener Neustadt (Austria). It produced huge amounts of well-processed and low-cost spruce seeds. The significant impact of the Central European seed industry in Poland is also reflected by numerous advertisements of Austrian seed traders in Polish forestry journals and by frequent contributions of Julius Stainer (owner of the biggest seed trading company in Wiener Neustadt) to the Polish forestry scientific dialogue during that time (e.g. Dering 2008). However, during the twentieth century, the production of local seed sources increased and subsequently greatly exceeded domestic demands, making the use of local FRM very likely (Matras 2013).

In Romania, the first plantings of Norway spruce were reported at the end of the nineteenth century, mainly in Transylvania, in the region Banat, Bucovina and north of the Moldova (Georgeta Mihai, personal communication; Schmidt-Vogt 1977). Furthermore, this tree species was spread far beyond its natural distribution in the Carpathian and Bihor Mountains (Schmidt-Vogt 1977). Between the end of nineteenth century and 1930, large amounts of Alpine seed sources were used along the Carpathian Arc (Figs. 2 and 3) (Marcu 1980). In the early twentieth century, attempts were made to replace broadleaved forests with conifers. Aside from local seed sources, large amounts of Austrian seeds, mainly obtained from the company Julius Stainer (Wiener Neustadt, Austria), were also employed (Ichim 1988). During the last century, the area covered by Norway spruce constantly increased, and between the periods 1929 and 2008, nearly 361,000 ha were planted (Georgeta Mihai, personal communication).

\subsection{Northern Europe}

In the Scandinavian Peninsula, Norway spruce has a large native distribution area but nevertheless, it has been highly affected by humans, especially in Southern Sweden, Denmark and Western Norway (e.g. Aarrestad et al. 2014; Almäng 1996; Eggertsson et al. 2008; Myking et al. 2016; Schmidt-Vogt 1977). Norway spruce is not native to Denmark, but was introduced to North Zealand along with several other conifer species in the eighteenth century (Schmidt-Vogt 1977) and has spread to Jutland Heath and other poor agricultural sites (Holmsgaard 1966). In the midtwentieth century, approximately 200,000 ha (Tulstrup 1959) had been afforested in Denmark, primarily with seeds from Germany (e.g. Thuringian Forest) (Fuhrmann 1926; Holmsgaard 1966). Subsequent afforestations were mostly performed with seed material originating from Northern Germany and to a lesser extent from Norway and Sweden. Carpathian seeds were also used in the years around 1970; however, in general, they performed poorly (Jansson et al. 2013).

At the beginning of the nineteenth century, Sweden and Norway also started to import large amounts of foreign conifer seeds (Aarrestad et al. 2014; Almäng 1996; Rohmeder 1972) (Fig. 2). Detailed records are again not available, but seed origins from Germany and Austria are probable. A northward transfer from Central Europe is also supported by the fact that large amounts of Scots pine seeds were transferred from Germany to Scandinavia starting in the eighteenth century (e.g. Fuhrmann 1926; Rohmeder 1972). A negligible use of French, Belgian or Hungarian seeds is possible (Almäng 1996). Most cultivations at that time originated from a mixture of different provenances (Skrøppa and Kohmann 1997).

In the early twentieth century, imports of spruce seeds increased, and between 1899 and 1950, more than 88,000 kg were introduced to Sweden from Germany (50\%), Denmark (22\%), Finland (8\%) and unknown countries (Almäng 1996). Lundkvist and Rudin (1977) also mentioned imports from the Baltic States (Fig. 3). More precise data are available for the years $1920-1922$, when nearly $6000 \mathrm{~kg}$ of spruce seeds were obtained by Sweden from the Black Forest in Southern Germany (Tulstrup 1959). In the second half of the twentieth century, more than $50 \%$ of used FRM originated from Eastern Europe (Romania, the Czech Republic, Belarus or Northern Poland), while the remaining demand was satisfied by local sources (Hannerz and Almäng 1997; Krutzsch 1982). Due to the substantial import of FRM, it is difficult to determine autochthonous populations with any confidence in Southern Sweden (Allmäng 1996). Laikre et al. (2006) indicated inaccuracies in the Swedish statistics between 1950 and 1994 by distinguishing between real imports and contract production. They conclude that a high proportion of the 2 billion plants introduced within the 35-year period to Sweden originated from Central Europe.

Norwegian imports of spruce seeds between 1952 and 2013 were about $29,000 \mathrm{~kg}$, roughly representing a potential cultivation area of 1 million ha (Aarrestad et al. 2014). An area 
of approximately 150,000 ha was covered by spruce outside the natural range at the turn of the twenty-first century (Jannson et al. 2013). Due to missing historic data, the overall impact of allochthonous FRM remains uncertain. Almost $94 \%$ of the introduced seeds originated from southern sources, mainly from Germany and Austria and to a lesser amount from Slovenia and Poland. Minor imports have also been reported from Sweden, Belarus, Denmark, Finland, Romania, Russia, Estonia and Bulgaria (Aarrestad et al. 2014). Afforestations established with spruce FRM transferred from a more southern origin partly outperformed local provenances in growth (Rohmeder 1972; Skrøppa and Dietrichson 1986). However, particularly, Central European provenances are vulnerable to winter damage, due to later growth cessation and hardiness development (Skrøppa and Dietrichson 1986).

\subsection{Congruence between records of historic transfer and genetic data}

Fortunately, Norway spruce has been intensively studied by molecular methods across Europe and clinal or even discontinuous variation patterns can be used for a very coarse (e.g. Morgante and Vendramin 1991) or more precise assignment (e.g. Tollesfrud et al. 2008) (for review, see Jansson et al. 2013). Most studies used putatively autochthonous stands to study the natural genetic structure. However, allozyme studies indicated a transfer in the Northern Black Forest (former region of Württemberg, see Online Resource Fig. 1) (Konnert 1991) and in the Harz Mountains where high altitudinal, autochthonous provenances were substituted by low altitudinal seed sources (Greger 1992).

Especially valuable are genetic studies using mitochondrial haplotypes (Gugerli et al. 2001). Populations which are probably of autochthonous origin (e.g. at high elevation which were historically difficult to exploit) can then be used to construct a genetic baseline for comparison with managed stands (Konrad et al. 2011; Geburek et al. 2016). Although Tollesfrud et al. (2008) have tried to collect only natural populations, some of their results indicate historic transfer. In particular, the distribution of certain genetic variants, in the mitochondrial genome (haplotype 746, 812, 842), signalled putative translocations throughout the natural range (Fig. 4). As an example, haplotype 812 is mainly present in Eastern Austria where also a major seed trading and processing centre was found in the past. However, this genetic variant is also occasionally found in the Southern Carpathians, Transylvania and Southern Poland. This finding is very likely due to anthropogenic translocations as the spatial distribution also coincides with the former Austrian Empire; and a strong influence of Austrian foresters in Poland, Romania or the Czech Republic during that time was reported (e.g. Bardecki 1909; Dering 2008; Lewandowski et al. 2012, 2014). Furthermore, the occurrence of this haplotype in this region contradicts the postglacial recolonization routes in East Central Europe (e.g. Dering and Lewandowski 2009; Schmidt-Vogt 1977). A similar pattern is also found for haplotype 842 . Populations which are characterized by this genetic variant may have had their refugia in the Bohemian Forest and its vicinity (Tollefsrud et al. 2008). This haplotype frequently also occurs in Eastern Austria, south-eastern Germany, the south-west of the Czech Republic and southwestern Poland. Its scattered distribution in the Carpathian Mountains (Romania), Central/Northern Poland, Southern Sweden and Estonia indicate artificial seed transfer. Besides Estonia, historic translocations from Central Europe were reported for all of these regions (e.g. Almäng 1996; Dering 2008; Lewandowski et al. 2012; Marcu 1980). Chen et al. (2012) investigated Swedish and Finnish spruce populations using single-nucleotide polymorphisms and used a Russian and an Alpine population as references. One Swedish population located south of Lake Vänern probably originated from the German Alpine region. Translocation of German and Baltic sources to Sweden could be already detected by isozyme analysis, as the degree of polymorphism at one of the two gene loci encoding leucine-aminopeptidase is extremely low in Germany, moderate in the Baltic area and high in Sweden (Bergmann 1977; Lundkvist and Rudin 1977). Human impact on the gene pool of P. abies in Eastern Europe (Northern and Southern Poland) is also supported by Nowakowska (2009). High frequencies of haplotype 842 were found in the southern and northern parts of Poland in the historic regions of Galicia and Pomerania. Since both regions were heavily influenced by Austrian and German forestry, a human-mediated distribution of this haplotype is very likely (Dering 2008). Moreover, human-mediated seed transfers are also supported by Lewandowski et al. (2012, 2014). Relatively high frequencies of "Alpine" and "Carpathian" haplotypes were found in populations in north and northeastern Poland and former Prussia (e.g. Fuhrmann 1926). For instance, in the Kartuzy forest district in former Pommeria (located outside the native range of Norway spruce), nearly $60 \%$ of the tested populations were of Alpine origin (Lewandowski et al. 2014); but high frequencies of "non-native" haplotypes were also detected in the Gołdap forest district which is located within the natural range of the species. This is also noteworthy as several spruce stands in this region are certified seed stands (EUFGIS 2016; Lewandowski et al. 2012).

Allochthonous seed sources were often used in the Czech Republic, especially during the period between 1840 and 1925 (Fanta 1974; Lüdemann 1978). Here, different haplotypes $(815,842,874$ only in the Southern Czech Republic) are common (Tollesfrud et al. 2008; supplemental Fig. 1a) and therefore, any conclusion concerning a seed transfer based on the present haplotype distribution is not possible. 
Fig. 4 Geographic distribution of haplotype 746,812 , and 842 of the minisatellite region of the mitochondrial nad1 gene based on Tollesfrud et al. (2008), Mengl et al. (2009), and Konrad et al. (2011)

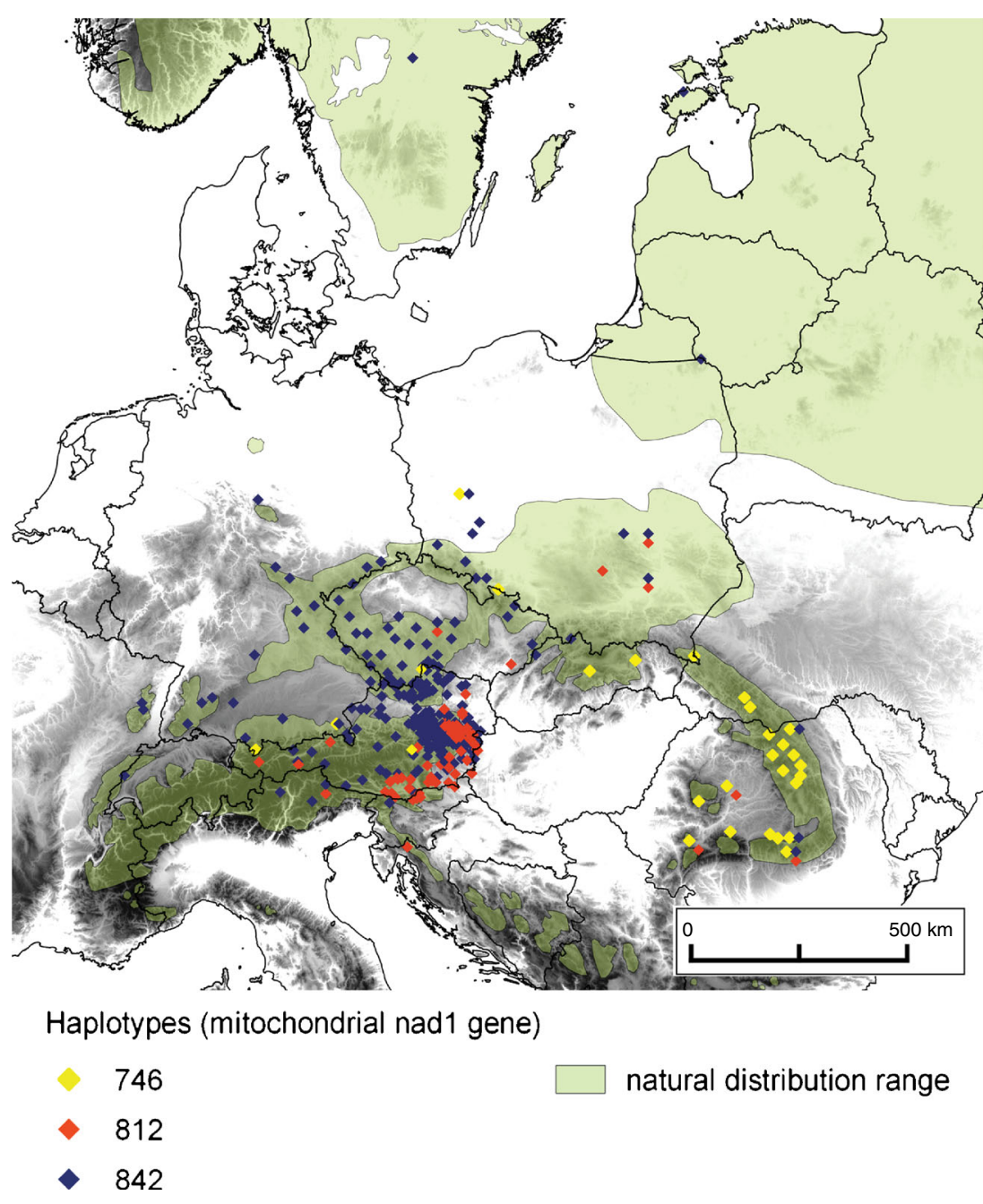

For Austria, the comparison of the data provided by Tollesfrud et al. (2008) and the detailed haplotype distribution in Austria (Mengl et al. 2009; Konrad et al. 2011) revealed putative translocations, which have not been confirmed by historic records. Haplotype 746 is frequently distributed in the Carpathian Mountains, where it had its presumed glacial refugia during the last glacial period (Fig. 2). The scattered distributions of haplotype 746 in Austria, as well as contradicting recolonization routes (e.g. Dering and Lewandowski 2009), indicate human influence. Moreover, this genetic variant exclusively occurs in commercial forest populations (e.g. Salzburg, Lower Austria). The distribution of haplotypes characteristic for the Carpathian Mountains also indicates seed transfers to Northern Austria (cf. Tollesfrud et al. 2008; Konrad et al. 2011).

\section{Impact on local adaptation}

Translocations can interfere with local adaptation by affecting the recipient gene pool: positively by enhancing the frequency of pre-adapted genes or negatively when maladapted genes are immigrating (e.g. FAO 2014; Frank et al. 2017). Especially in regard to rapid climatic change, hybridization with pre-adapted genotypes can be a significant factor to mitigate adaptational lags (e.g. Aitken and Bemmels 2016; Frank et al. 2017). In particular, this might be the case for species such as Norway spruce which exhibit a high intraspecific adaptive differentiation with strong environmental specialization (Frank et al. 2017). The loss of induced fitness is denoted as migration load. This load can be subdivided into (1) the standing load which causes a continual loss of fitness, since genes of the recipient population are not yet fixed due to stabilization selection, genetic correlations and breaking up linkage disequilibria by segregation/recombination, hence creating an existing phenotypic variance around the optimum, and (2) the lag load that results from deviation of the mean population phenotype from the local selective optimum. Both components are inversely related to the width of stabilizing selection (a measure of the strength of stabilizing selection; for further discussion, see Bridle et al. 2009). Therefore, the genetic impact of a translocation depends on the genetic 
composition of the recipient populations and the environmental difference between the original site and the site of translocation (Kopp and Matuszewski 2014). Poorly adapted phenotypes that could spread their genes after reaching maturity therefore decrease local adaptation in successive generations (Mijnsbrugge et al. 2010; Millar and Libby 1989).

For instance, Dietrichson (1991) showed in Østlandet (south-eastern Norway) that $5-10 \%$ of the progenies were intraspecific hybrids although only $4 \%$ of the trees were allochthonous. However, negative consequences of using Norway spruce FRM from unknown sources have not been as obvious as in Scots pine (Timbal et al. 2005). For instance, southern Fennoscandian spruce populations have been intensively affected by Central European provenances, but major failure associated with transfer are not reported (Myking et al. 2016). However, Sweden imported large amounts of Czech, Slovak and Belarusian FRM, provenances that have proven their adaptational plasticity (e.g. Ujvári-Jármay et al. 2016). Furthermore, Norway spruce possesses a large intraspecific genetic variation (e.g. Collignon et al. 2002) that may promote a fast adaptation by natural selection (Modrzyński 2007). The use of large seed amounts and dense planting, frequently reported for historic cultivations, may have favoured adapted individuals (e.g. Myking et al. 2016).

In general, Krutzsch (1992) attributed to Norway spruce a higher environmental tolerance than, for instance, Scots pine (Modrzyński 1995). Furthermore, P. abies maintains a mechanism of epigenetic memory which is triggered by different weather conditions, mainly temperature, during embryo development. Bud burst phenology is under epigenetic control (e.g. Johnsen et al. 2005, Yakovlev et al. 2010) causing a rapid adaptation in translocated populations to become more similar to local populations. Skrøppa et al. (2010) showed, for instance, fast adaptation in bud set phenology from only one generation to the next in Central European provenances planted in Northern Europe. This is also in line with the results of Kramer et al. (2013) who assumed a rapid adaptation of tree populations in phenology and water use within two or three regeneration circles. In any case, reasons for a bad performance have to be carefully evaluated and may be caused by a combination of several risk factors, such as silvicultural management, site conditions or provenance choice. For instance, in Northern Europe, several cultivations that suffered from climate damages had been suspected to be of Central European origin, while a genetic analysis proofed later their native character (Skrøppa et al. 2010).

Translocations of FRM may also improve forest growth and survival and may even increase - besides productivitythe stability of tree populations (e.g. Giertych 2007). This is due to a smaller adaption lag that certain allochthonous populations encounter. For instance, several provenances from Baltic countries or Central and Eastern Europe have proven their suitability in Scandinavia (e.g. Rohmeder 1972). In regard to climate change, a northward transfer of Eastern European provenances may be beneficial by avoiding frost damage in spring as bud burst has already advanced (Myking et al. 2016). Gomöry et al. (2012) confirmed a positive feedback in height and volume growth for provenances transferred to warmer conditions with less precipitation, what equals the manifold historic transfer of spruce seeds to lower elevations. Especially, provenances from the Harz Mountains (Germany), the Sudetes and the Beskid Mountains performed well in Western Norway, while seeds originating from northeastern Poland, Lithuania and Belarus have been recommended for Southern and Eastern Norway (Magnesen 1972; Giertych 2007).

Associations between historic and molecular data, as discussed above, may indicate the persistent impact of allochthonous genes in present-day populations. Moreover, molecular data based on mitochondrial markers do not reveal gene flow by pollen, and may underestimate the impact of nonnative translocations (e.g. Finkeldey et al. 2000). Results may be biased also by the fact that most studies have only been performed in putatively autochthonous populations and the true extent of admixture in managed forests may be underestimated.

\section{Concluding remarks}

It is difficult to assess the actual impact of translocation on current populations, since historic records are vague; frequently, data are missing about the origin of FRM, the traded amounts, cultivation places or the success of cultivations. However, historic records can at least provide clues about where and with which seed sources the distribution area of Norway spruce has been enlarged. Furthermore, these data highlight regions where the natural gene pool has probably been affected by translocations (e.g. Jansen and Geburek 2016).

While the south of Sweden and Norway have been substantially affected by seed from Central and Eastern Europe, we infer only a marginal impact of allochthonous seed sources in the northern parts of the Baltic-Nordic region. In contrast, the gene pool of $P$. abies in Central and Eastern Europe has been significantly altered by man. Alpine provenances in particular were exported to the Hercyno-Carpathian range (Figs. 2 and 3). As provenances from the HercynoCarpathian distribution are known for their broad phenotypic plasticity (e.g. Ujvári-Jármay et al. 2016), further tests on the genetic composition of current populations are suggested. However, a frequent transfer of apparently inappropriate seed sources to Eastern Europe has not been reported (see also Table 1) (Bergmann 1965; Giertych 2007; König 2005; Konôpka and Šimak 1990; Ujvári-Jármay et al. 2016). 
As demonstrated in this review, backtracking of historic translocations is complex and frequently suffers from incomplete records. Hence, we emphasize the importance of record keeping of seed transfer on an intra- and international level, this was already proposed by several authors (e.g. Konnert et al. 2015; Koskela et al. 2007). Although today the trade of FRM is regulated by European law (Council Directive 1999/105/EC) and tree breeding programmes have been implemented in most European countries (for review see: Pâque 2013), record keeping on seed sources used is not mandatory and its usefulness is not recognized by most forest managers.

In the last decades, ecological issues became a keystone in European forest policy. The increasing integration of nongovernmental institutions, as well as a growing public awareness of forest issues (e.g. Regulation (EU) No. 1293/2013), challenges our knowledge about the naturalness and biodiversity of forest ecosystems. Several legal and politically binding regulations (e.g. Oslo Ministerial Decision: European Forests 2020) or scientific initiatives (e.g. EEA 2014; Ferris and Humphrey 1999; Lier et al. 2013; van Loy et al. 2003) highlight the significance of this issue. Norway spruce has been acknowledged as a key species in European gene conservation efforts, and the identification and protection of autochthonous populations have been implemented in several national gene conservation strategies (e.g. Koski et al. 1997; Paul et al. 2010). The identification of autochthonous populations, as well as stands most susceptible to climatic and environmental changes, remains an urgent task (Spiecker 2000).

Acknowledgements We would like to thank Petr Škorpik for translations from Czech and Monika Dering, Andrzej Lewandowski, Antoine Kremer, Tor Myking and the library team of the Austrian Research Centre of Forests for their help in obtaining relevant literature. Additionally, we want to thank the EUFORGEN programme for maintaining and further developing the EUFGIS database. We further want to thank the reviewers for their detailed comments that significantly helped to improve the manuscript.

\section{Compliance with ethical standards}

Funding This work was supported by the 7th EU Framework Programme (Project: FORGER Towards the Sustainable Management of Forest Genetic Resources in Europe).

\section{References}

Aarrestad PA, Myking T, Stabbetorp OE, Tollesfrud MM (2014) Foreign Norway spruce (Picea abies) provenances in Norway and effects on biodiversity. Nina Rep 1075

Aitken SN, Bemmels JB (2016) Time to get moving: assisted gene flow of forest trees. Evol Appl 9:271-290

Almäng A (1996) Utländska gran- och tallprovenienser i svenskt skogsbruk: Foreign provenances of Norway spruce and Scots pine in Swedish forestry. Arbetsrapport/Sveriges lantbruksuniversitet, Institutionen för skoglig genetik och växtfysiolog 54
Bałut S (1962) Zmienność niektórych cech w populacjach modrzewi z gor świetokrzyskich, Beskidów i Sudetów jako podstawa wyrózniania gospodarczo cennych ekotypów. Acta Agrar Silv Ser Lesn (Krak) 2:3-43

Bardecki A (1909) Zużytkowanie krajowych nasion leśnych. Sylwan 11: $30-34$

Bartoli M (2003) La dynamique naturelle de l'epicea (Picea abies [L.] Karst..) dans les pyrenees françaises. Acta Bot Barcinon 49:281290

Bartoli M, Demesure-Musch B (2003) Plus d'un siècle d'intervention humaine dans les flux des gènes des pin à crochets et sapin français. Rev For Fr 55:546-556

Bendix B (2008) Die Geschichte der Forstpflanzenzucht in Deutschland von ihren Anfängen bis zum Ausgang des 19. Jahrhunderts, Kessel, Remagen-Oberwinter

Berard A (1959) Les reboisements artificiels dans les forêts vosgiennes au XIX siêcle. Rev For Fr 5:371-375

Bergmann F (1965) Moving spruce provenances in central Norrland. Arsb Foren Skogstradsforadl Stockholm 1964:85-103

Bergmann F (1977) Identification of forest seed origin by means of isoenzyme gene frequencies. EEC Symposium of Forest Tree Biochenstry, Session Document 6:151-162

Blahá J (undated) Spruce monocultures in the Czech Republic - the Sumuva Mountains case studies. In A compilation of testimonies on the negative impact of large-scale monoculture tree plantationsprepared for the sixth conference of the parties of the framework convention on climate change. A friend of the earth international, pp $38-45$

Borchers K (1967) Niedersachsen; Fichte, Picea abies [L.] Karst. In: Puchert $\mathrm{H}$ (ed) Wertvolle Herkünfte forstlicher Baumarten in der Bundesrepublik Deutschland, 1st edn. Bayerischer Landwirtschaftsverlag, München, Basel, Wien, pp 169-187

Bouvarel P (1958) Les repeuplements artificiels - consequences d'ordre génétique. Schweiz Z Forstwes 109:524-536

Bouvarel P (1965) Die Französischen Fichtenherkünfte für Gebirgsaufforstungen. In: Schmidt-Vogt H (ed) Forstsamengewinnung und Pflanzenzucht für das Hochgebirge. BLV, München, pp 41-53

Bradshaw RHW (2004) Past anthropogenic influence on European forests and some possible genetic consequences. For Ecol Manag 197: 203-212

Bridle JR, Polechova J, Vines TH (2009) Limits to adaptation and patterns of diversity. In: Butlin RK, Bridle JR, Schluter D (eds) Speciation and patterns of diversity, 1st edn. Cambridge University Press, Cambridge, pp 77-102

Brown JC (1880) Reboisement in France. C.K. Kegan Paul \& Co, London

Budeanu M, Şofletea N, Pârnutâ G (2012) Testing Romanian seed sources of Norway spruce (Picea abies): results on growth traits and survival at age 30. Ann For Res 55:43-52

Chen J, Källman T, Ma X, Gyllenstrand N, Zaina G, Morgante M, Bousquet J, Eckert A, Wegrzyn J, Neale D, Lagercrantz ML (2012) Disentangling the roles of history and local selection in shaping clinal variation of allele frequencies and gene expression in Norway spruce (Picea abies). Genetics 191:865-881

Collignon AM, Van de Sype H, Favre JM (2002) Geographical variation in random amplified polymorphic DNA and quantitative traits in Norway spruce. Can J For Res 32:266-282

Council Directive (1999)/105/EC of 22 December 1999 on the marketing of forest reproductive materia. OJ of the EU. L 240: 34-38

Dering M (2008) Postglacial migration of Norway spruce (Picea abies [L.] Karst.) in Poland based on molecular markers. Dissertation, Polskiej Akademii Nauk

Dering M, Lewandowski A (2009) Finding the meeting zone: where have the northern and southern ranges of Norway spruce overlapped? For Ecol Manag 259:229-235 
Dietrichson J (1991) Genspredning fra plantet mellomeuropeisk gran (Picea abies [L.] Karst.) på Syd-Østlandet. Rapport fra Skogforsk $11: 1-11$

Dingethal FJ (1970) Der Wald der Stadt Weißenburg (Bayern) Umformung eines Mittelwaldbetriebes und Aufbau der Folgebestände. Beih Forstwiss Centralbl 31:1-72

Duterme CJ (1962) Réflexions sur la culture de l'épicea en Belgique. Bull Soc For Belgique 69:173-186

EEA (2014) European forest ecosystems - state and trends. EEA Report 5, European Environment Agency, pp. 128.

Eggertsson O, Nygaard PH, Skovsgaard JP (2008) History of afforestation in the Nordic countries. TemaNord 562:15-27

Elsner F (1967) Bayern; Fichte, Picea abies [L.] Karst. In: Puchert H (ed) Wertvolle Herkünfte forstlicher Baumarten in der Bundesrepublik Deutschland, 1st edn. Bayerischer Landwirtschaftsverlag, München, Basel Wien, pp 63-66

Endres M (1905) Handbuch der Forstpolitik. Julius Springer, Berlin

EUFGIS (2016) Gene conservation units. http://portal.eufgis.org/geneticconservation-units. Accessed 31 May 2016

Fanta J (1974) Morphologische Variabilität der Fichte und Grundzüge der genetischen Rekonstruktion der Gebirgsfichtenwälder im Karkonoše Nationalpark (ČSSR). Arch Naturschutz u Landschaftsforsch 3:179-200

FAO (2014) Drivers of change and trends affecting forest genetic resources. In: FAO (ed) The state of the world's Forest genetic resources, 1st edn. Commission on Genetic Resources for Food and Agriculture, Rome, pp 51-64

Ferris R, Humphrey JW (1999) A review of potential biodiversity indicators for application in British forests. Forestry 72:313-328

Finkeldey R, Mátyás G, Sperisen C, Bonfils P (2000) Strategien zur Auswahl forstlicher Genreservate in der Schweiz. For Snow Landsc 75:137-152

Forestry Commission (2011) NFI 2011 woodland map GP. Forestry Commission, National Forest Inventory, Edinburgh

Frank A, Sperisen C, Howe GT, Brang P, Walthert L, St.Clair BJ, Heiri C (2017) Distinct genecological patterns in seedlings of Norway spruce and silver fir from a mountainous landscape. Ecology 98: 211-227

Fuhrmann E (1926) Das Forstsaatgut in der deutschen Volkswirtschaft. Abhandlungen des wirtschaftswissenschaftlichen Seminars in Jena 17, Gustav Fischer, Jena

Gadant J (1968) Le reboisement en Auvergne. Rev For Fr 7(8):449-457

Gathy P (1960) L'órigin des grains epicea commun. Bull Soc Roy For Belgique 67:381-394

Geburek T (2005) Genetic diversity in forest trees - its importance and potential human impact. In: Geburek T, Turok J (eds) Conservation and management of forest genetic resources in Europe, 1st edn. Arbora Publishers, Zvolen, pp 437-458

Geburek T, Turok J (2005) Conservation and sustainable management of forest genetic resources in Europe - an introduction. In: Geburek T, Turok J (eds) Conservation and management of forest genetic resources in Europe, 1st edn. Arbora Publishers, Zvolen, pp 3-9

Geburek T, Robitschek K, Milasowszky N, Schaudauer K (2007) Different cone colours pay off: lessons learnt from European larch (Larix decidua) and Norway spruce (Picea abies). Can J Botany 85: 132-140

Geburek T, Robitschek K, Milasowszky N (2008) A tree of many faces: why are there different crown types in Norway spruce (Picea abies [L.] Karst.) Flora 203:126-133

Geburek T, Büchsenmeister R, Englisch M, Frank G, Hauk E, Konrad H, Liebmann S, Neumann M, Starlinger F, Steiner H (2016) Austrian biodiversity index - concepts and evaluation, BFW-Berichte 151. http://bfw.ac.at/webshop/index.php. Accessed 20 February 2017

Giertych M (2007) Provenance variation and inheritance. In: Tjoelker MG, Boratyński A, Bugała W (eds) Biology and ecology of Norway spruce, 1st edn. Springer, Berlin, pp 115-146
Gomöry D, Longauer R, Hlásny T, Pacalaj MS, Krajmerová D (2012) Adaptation to common optimum in different populations of Norway spruce (Picea abies Karst.) Eur J For Res 131:401-411

Graudal L, Aravanopoulos F, Bennadji Z, Changtragoon S, Fady B, Kjaer ED, Loo J, Ramamonjisoa L (2014) Global to local genetic diversity indicators of evolutionary potential in tree species within and outside forests. For Ecol Manag 333:35-51

Greger O (1992) Erfassung von Relikten des autochthonen Fichtenvorkommens im Hochharz, vol 44. Aus dem Walde Mitteilungen der Niedersächsischen, Landesforstverwaltung, pp 1319

Gugerli F, Sperisen C, Büchler U, Magni F, Geburek T, Jeandroz S, Senn J (2001) Haplotype variation in a mitochondrial tandem repeat of Norway spruce (Picea abies) populations suggests a serious founder effect during postglacial re-colonization of the western Alps. Mol Ecol 10:1255-1263

Haack NN (1909) Die Beschaffung des Kiefern- und Fichtensamens einst, jetzt und künftig. Mitteilungen des deutschen Forstvereins 6: $137-167$

Hausrath H (1908) Kleine Beiträge zur Geschichte der künstlichen Verjüngung. Allg Forst- Jagdztg 84:47-50

Hannerz M, Almäng A (1997) Utlanländska gran- og och tallprovenienser i svenskt skogsbruk.Skogforsk Resultat No 7

Holmsgaard E (1966) Nadelholzanbau in Dänemark. Forstwiss Centralbl $85: 38-59$

Hornstein F (1958) Wald und Mensch. Otto Maier Verlag, Ravensburg

Ichim R (1988) Istoria padurilor si silviculturii din Bucovina. Editura Ceres, Bucharest

Immel R (1933) Beiträge zur Frühgeschichte der Nadelholzkultur und der Holzartenverbreitung in Hessen. Allg Forst- Jagdztg 109:173-184

Jansen S, Geburek T (2016) Historic translocations of European larch (Larix decidua Mill.) genetic resources across Europe - a review from the 17th until the mid-20th century. For Ecol Manag 379: 114-123

Jansson G, Danusevičius D, Grotehusman H, Kowalczyk J, Krajmerova D, Skrøppa T, Wolf H (2013) Norway spruce (Picea abies [L.] H. Karst.) In: Pâques LE (ed) Forest tree breeding in Europe; current state-of-the-art and perspectives, managing forest ecosystems, $1 \mathrm{st}$ edn. Springer, Dordrecht, Heidelberg, New York London, pp 123177

Jeleček L (1973) Vývoj lesnatosti Čech ve 2. polovině 19. století. Hist Geogr 10:177-205

Johnsen Ø, Fossdal CG, Nagy N, Mølmann J, Dæhlen OG, Skrøppa T (2005) Climatic adaptation in Picea abies progenies is affected by the temperature during zygotic embryogenesis and seed maturation. Plant Cell Environ 28:1090-1102

Kaplan JO, Krumhardt KM, Zimmermann N (2009) The prehistoric and preindustrial deforestation of Europe. Quat Sci Rev 28:3016-3034

Kappes U (1972) Zur Anbaugeschichte und Standortbedingten Entwicklung Kurhessischer Mischbestände aus Kiefer, Fichte und Lärche. Dissertation, Georg-August-Universität Göttingen

Kirschfeld P (1967) Baden-Württemberg; Fichte, Picea abies [L.] Karst. In: Puchert $\mathrm{H}$ (ed) Wertvolle Herkünfte forstlicher Baumarten in der Bundesrepublik Deutschland, 1st edn. Bayerischer, Landwirtschaftsverlag, München, Basel Wien, pp 38-40

Klimo E (1992) The spruce forest ecosystem in Czechoslovakia. In: Teller A, Mathy P, JNR J (eds) Responses of forest ecosystems to environmental changes, 1st edn. Springer, Dordrecht, Heidelberg. New York, London, pp 503-511

Klimo E, Hager H, Kulhavý J (2000) Spruce monocultures in Central Europe - problems and prospects. EFI Proc 33:5-9

Kmet J, Ditmarová L', Priwitzer T, Kurjak D (2010) Úloha fyziologických aspektov v odumieraní smrečín. In: Kulla L, Sitková Z (eds) Hynutie a rekonštrukcie smrečín na Slovensku-Recenzovaný zborník odborných prác vydaný na DVD. NLC, LVÚ, Zvolen, pp 113-122 
Köhler R (1952) Erste Entwicklung der Fichtenkultur im Harz. Forst Holz $7: 1-139$

König AO (2005) Provenance research: evaluation the spatial pattern of genetic variation. In: Geburek T, Turok J (eds) Conservation and management of forest genetic resources in Europe, 1st edn. Arbora Publishers, Zvolen, pp 275-333

Konnert M (1991) Die Fichte (Picea abies [L.] Karst.) im Schwarzwald: Genetische Variation und Korrelationen. Forstwiss Centralbl 110: 84-94

Konnert M (2009) Genetic variation of Picea abies in southern Germany as determined using isozyme and STS markers. Dendrobiology 61s: $131-136$

Konnert M, Fady B, Gömöry D, A'Hara S, Wolter F, Ducci F, Koskela J, Bozzano M, Maaten T, Kowalczyk J (2015) Use and transfer of forest reproductive material in Europe in context of climate change. European Forest Genetic Resources Programme (EUFORGEN), Bioversity International, Rome

Konôpka J, Šimak M (1990) Rast a statické vlastnosti výškových proveniencií smreka obyčajného na trvalých výskumných plochách v SR. Lesnictví 36:825-842

Konrad H, Mengl M, Geburek T (2011) Genetische Inventur der Fichte in Österreich: große Vielfalt, unterschätze Naturnähe. BFWPraxisinformation 24:22-24

Kopp M, Matuszewski S (2014) Rapid evolution of quantitative traits: theoretical perspectives. Evol Appl 7:169-191

Koskela J, Buck A, Teissier du Cros E (eds) (2007) Climate change and forest genetic diversity: implications for sustainable forest management in Europe. Bioversity International, Rome

Koskela J, Lefèvre F (2013) Genetic diversity of forest trees. In: Kraus D, Krumm F (eds) Integrative approaches as an opportunity for conservation of forest biodiversity, 1st edn. European Forest Institute, Erfurt, pp 232-241

Koskela J, Vinceti B, Dvorak W, Bush D, Dawson IK, Loo J, Kjaer ED, Navarro C, Padolina C, Bordács S (2014) Utilization and transfer of forest genetic resources: a global review. For Ecol Manag 333:2234

Koski V, Skröppa T, Paule L, Wolf H, Turok J (1997) Technical guidelines for genetic conservation of Norway spruce (Picea abies [L.] Karst.) International Plant Genetic Resource Institute, Rome

Kramer K, Hengeveld GS, van der Werft B, de Winter W (2013) Genetic adaptive response: missing issue in climate change assessment studies. In: Proceedings of the Impact World 2013 conference. Potsdam, Germany, pp 27-30

Kremser W (1990) Niedersächsische Forstgeschichte-Eine integrierte Kulturgeschichte des nordwestdeutschen Forstwesens. Heimatbund Rotenburg/Wümme, Rotenburg

Krutzsch H (1952) Waldaufbau. Deutscher Bauernverlag, Berlin

Krutzsch P (1982) Forest gene resources in Sweden. Silva Fenn 16:215219

Krutzsch P (1992) IUFRO's role in coniferous tree improvement: Norway spruce (Picea abies [L.] Karst.) Silvae Genet 41:143-150

Kulla L (2011) História nepôvodných smrekových lesov v oblasti Kysúc. In: L. Kulla, Z. Sitková (eds) „Hynutie a rekonštrukcie smrečín na Slovensku“ Recenzovaný zborník odborných prác vydaný na DVD, NLC, LVÚ, Zvolen, pp1-14

Laikre L, Palmé A, Josefsson M, Utter F, Ryman N (2006) Release of alien populations in Sweden. Ambio 35:255-261

Ledig FT (1992) Human impacts on genetic diversity in forest ecosystems. Oikos 63:87-108

Lewandowski A, Litkowiec M, Grygier A, Dering M (2012) Weryfikacja pochodzenia świerka pospolitego (Picea abies) w Nadleśnictwie Gołdap. Sylwan 156:494-501

Lewandowski A, Szydlarski M, Litkowiec M (2014) Pochodzenie świerka pospolitego (Picea abies [L.] Karst.) w Nadleśnictwie Kartuzy. Sylwan 158:509-515
Lier M, Parviainen J, Nivet C, Gosselin M, Gosselin F, Paillet Y (2013) The use of European criteria and indicator systems for measuring changes in forest biodiversity. In: Kraus D, Krumm F (eds) Integrative approaches as an opportunity for the conservation of forest biodiversity, 1st edn. Freiburg, European Forest Institute, pp $32-42$

Lines R (1987) Choice of seed origins for the main forest species in Britain. Forestry Commission Bulletin No. 66. HMSO.

Lokvenc T (1989) Introdukce jehličnattých dřevin do lesních porostu Krkonos. Opera Corcon 26:61-89

Lüdemann G (1978) Die Rolle der deutschen Forstbaumschulen bei der Herkunftssicherung forstlichen Saat- und Pflanzgutes. Allg Forstztg 37:32-35

Lundkvist K, Rudin D (1977) Genetic variation in eleven populations of Picea abies as determined by isozyme analysis. Hereditas 85:67-74

Magnesen S (1972) Experimental—økologiske undersøkelser over vekstavslutningen hos frøplanter av gran (Picea abies [L.] Karst.) Medd Vestl Forst Forsøksst 52:271-317

Mansfeld V (2011) Norway spruce in forest ecosystems of the Czech Republic in relation to different site conditions. J For Sci 57:514-522

Marcu Gh (1980) Cercetări privind extinderea culturii molidului în R.S. România, Editura, Bucharest

Matras J (2009) Growth and development of Polish provenances of Picea abies in the IUFRO 1972 experiment. Dendrobiology 61:145-158

Matras J (2013) Long term variability in seed crops of the main tree species in Poland. Presentation at International conference of European seed kilns, Bernkastel-Kues, Germany, 04-07

Matuszkiewicz W, Matuszkiewicz A (1960) Pflanzensoziologische Untersuchungen der Waldgesellschaften des Riesengebirges. Acta Soc Bot Pol 29:499-530

Mengl M, Geburek T, Schueler S (2009) Geographical pattern of haplotypic variation in Austrian native stands of Picea abies. Dendrobiology 61:117-118

Mihai G (2003) Researches of Norway spruce interpopulational genetic variability. Ann For Res 46:131-139

Mijnsbrugge KV, Bischoff A, Smith B (2010) A question of origin: where and how to collect seed for ecological restoration. Basic Appl Ecol 11:300-311

Millar CI, Libby WJ (1989) Disneyland or native ecosystems: genetics and the restorationist. Restor Manag Notes 7:18-24

Modrzyński J (1989) Środowiskowe przystosowanie I pochodzenie świerka pospolitego (Picea abies [L.] Karst.) w Karkonoskim parku narodowym. Rozprawy Naukowe 192, Wydawn

Modrzyński J (1995) Altitudinal adaptation of Norway spruce (Picea abies [L.] Karst.) progenies indicates small role of introduced provenances in the Karkonosze Mountains. Silvae Genet 44:70-75

Modrzyński J (2007) Ecology. In: Tjoelker MG, Boratyński A, Bugała W (eds) Biology and ecology of Norway spruce. Springer, Berlin, pp 195-220

Morgante M, Vendramin GG (1991) Genetic variation in Italian populations of Picea abies [L.] Karst. and Pinus leucodermis Ant. In: Müller-Starck G, Ziehe M (eds) Genetic variation in European populations of forest trees, 1st edn. J.D. Sauerlander's Verlag, Frankfurt a. Main, pp 205-227

Mullin TJ, Andersson B, Bastien JC, Beaulieu J, Burdon RD, Dvorak WS, King JN, Kondo T, Krakowski J, Lee SJ (2011) Economic importance, breeding objectives and achievements. In: Plomion C, Bousquet J, Kole C (eds) Genetics, genomics and breeding of conifers, 1st edn. CRC Press, Abingdon, pp 40-127

Myking T, Rusanen M, Steffenrem A, Kjær ED, Jansson G (2016) Historic transfer of forest reproductive material in the Nordic region: drivers, scale and implications. Forestry 89:325-337

Noël A (1882) Repeuplements Artificiels et al restauration des Vides \& Clairieres des Forêts. Berger-Levrault, Paris 
Nowakowska JA (2009) Mitochondrial and nuclear DNA differentiation of Picea abies populations in Poland. Dendrobiology 61:119-129

Nožička J (1967) Anfänge der Aufforstung und der künstlichen Verjüngung in der Tschechoslowakei 1243-1770. XIV. IUFROKongress, München, pp 57-67

Nožička J (1972) Původni výskyt smrku v českých zemich. Státní zemědělské nakladatelstui, Praha

Oberdorfer E (1937) Zur spät- und nacheiszeitlichen Vegetationsgeschichte des Oberelsasses und der Vogesen. Z f Bot 30:513-572

Pâque LE (ed) (2013) Forest tree breeding in Europe: current state-of-theart and perspectives, managing forest ecosystems, 1st edn. London, Springer, Dordrecht, Heidelberg, New York

Pardé J (1965) Waldbestände und Aufforstungen hoher Wuchsleistung in Frankreich. Wiss Z Tech Univ Dresden 2:403-405

Paul M, Hinrichs T, Janßen A, Schmitt HP, Soppa B, Dörflinger H (2010) Concept for the conservation and sustainable utilization of forest genetic resources in the Federal Republic of Germany. BMELV, Bonn

Pourtet J (1946) Les repeuplements artificiels. Ecole Nationale des Eaux et forêts, Nancy

Pourtet J (1952) Les concetions actuelles du reboisement en France. Schweiz Z Forstwes 103:137-151

Rachoy W (1971) Die Waldbauliche Entwicklung in den Wäldern des Praemonstratenser Chorherrn-Stiftes Schlägl im oberen Mühlviertel. Centralbl gesamte Forstwes 88:26-51

Rajora OP, Mosseler A (2001) Challenges and opportunities for conservation of forest genetic resources. Euphytica 118:197-212

Rausch H (1949) Die Verpflichtung der Forstwirtschaft in der deutschen Not. Allg Forstztg 7:58-62

Regulation (EU) No 1293. (2013) of the European Parliament and of the Council of 11 December 2013 on the establishment of a Programme for the Environment and Climate Action (LIFE) and repealing Regulation (EC) No 614/2007 Text with EEA relevance. OJ of the EU. L 347:185-208

Rohmeder E (1972) Das Saatgut in der Forstwirtschaft. Paul Parey, Hamburg, Berlin

Rossmässler W (1967) Hessen; Fichte Picea abies [L.] Karst. In: Puchert $\mathrm{H}$ (ed) Wertvolle Herkünfte forstlicher Baumarten in der Bundesrepublik Deutschland, 1st edn. Bayerischer Landwirtschaftsverlag, München, Basel, Wien, pp 96-103

Rubner K (1954) Die Wiederaufforstungen in Bayern von 1948 bis 1954. Bayerischer Landwirtschaftsverlag, München

Ruetz WF, Bergmann F (1989) Möglichkeiten zum Nachweis von autochthonen Hochlagenbeständen der Fichte (Picea abies) in den Berchtesgadener Alpen. Forstwiss Centralbl 108:164-174

Sabor J (2009) Research on the variability of Picea abies in Poland: genetic and breeding value of spruce populations in the Polish range of the species. Dendrobiology 61 supplement:7-13

Schmidt-Vogt H (1977) Die Fichte (1), 1st edn. Paul Parey, Hamburg, Berlin

Schoppa FN (2000) Konsequenzen wald- und forstgeschichtlicher Entwicklung für die aktuelle genetische Zusammensetzung von Waldbaumpopulationen in Mitteleuropa. Georg-August-Universität Göttingen, Dissertation

Schrötter FW (1967) Schleswig-Holstein; Fichte, Picea abies [L.] Karst. In: Puchert $\mathrm{H}$ (ed) Wertvolle Herkünfte forstlicher Baumarten in der Bundesrepublik Deutschland, 1st edn. Bayerischer Landwirtschaftsverlag, München, Basel, Wien, pp 247-251

Schwarz A (1903) Der Waldpflanzenzucht-Betrieb in und um Halstenbek. Forstwis Centralbl 25:472-502

Skrøppa T, Dietrichson K (1986) Winter damage in the IUFRO 1964/68 provenance experiment with Norway spruce (Picea abies (L.) Karst.) Comm Nor For Res Inst 39:161-183
Skrøppa T, Kohmann K (1997) Adaptation to local conditions after one generation in Norway spruce. For Genet 4:171-177

Skrøppa T, Tollefsrud M, Sprisen C, Johnsen Ø (2010) Rapid change in adaptive performance from one generation to the next in Pice abies - central European trees in a Nordic environment. Tree Genet Genomes 6:93-99

Šnytr O (2009) Vyhodnocení genových zdrojů lesních dřevin na území CHKO Jizerské hory. Dissertation, Czech university of life science, Prague

Spiecker H (2000) Growth of Norway spruce (Picea abies [L.] Karst.) under changing environmental conditions in Europe. In: Klimo E, Hager H, Kulhavý J (eds) Spruce monocultures in Central Europeproblems and prospects. EFI Proceedings, vol 33, pp 11-27

Spiecker H (2003) Silvicultural management in maintaining biodiversity and resistance of forests in Europe - temperate zone. J Environ Manag 67:55-65

Svoboda P (1943) Holzartenwechsel im Pürglitzer Walde. Centralbl gesamte Forstwes 69:65-87

Timbal J, Bonneau M, Landmann G, Trouvilliez J, Bouhot-Delduc L (2005) European non boreal conifer forests. In: Andersson FA (ed) Ecosystems of the world (6): coniferous forests. Elsevier, Amsterdam, pp 131-162

Tollefsrud MM, Kissling R, Gugerli F, Johnsen Ø, Skrøppa T, Cheddadi R, Van der Knaap WO, Latałowa M, Terhürne-Berson R, Litt T, Geburek T, Brochmann C, Sperisen C (2008) Genetic consequences of glacial survival and postglacial colonization in Norway spruce: combined analysis of mitochondrial DNA and fossil pollen. Mol Ecol 17:4134-4150

Tulstrup NP (1959) International trade in forest tree seed. Unasylva 13: 196-201

Ujvári-Jármay L, Nagy L, Mátyás CS (2016) The IUFRO 1964/68 inventory provenance trial of Norway spruce in Nyírjes, Hungary-results and conclusions of five decades. Acta Silvatica \& Lignaria Hungarica 12, Special Edition, pp 178

Ulbrichová I, Podrázský V, Beran F, Zahradník D, Fulín M, Procházka J, Kubeček J (2015) Picea abies provenance test in the Czech Republic after 36 years - Central European provenances. J For Sci 61:465-477

Van Loy K, Vandekerkhove K, Van Den Meersschaut D (2003) Assessing and monitoring the status of biodiversity-related aspects in Flemish forests by use of the Flemish forest inventory data. In: Corona P, Kohl M, Marchetti M (eds) Advances in forest inventory for sustainable forest management and biodiversity monitoring, 1st edn. Kluwer Academic Publishers, Dordrecht, Boston, London, pp 405-430

Vogel-Daniels A (1968) Die natürliche und künstliche Verbreitung der Fichte in Frankreich, Belgien und Luxemburg. Albert-LudwigsUniversität Freiburg im Breisgau, Dissertation

Volk H (1969) Untersuchungen zur Ausbreitung und künstlichen Einbringung der Fichte im Schwarzwald. Selbstverlag der Landesforstverwaltung Baden-Württemberg, Stuttgart

Wickneswari R, Rajora OP, Finkeldey R, Aravanopoulos F, Bouvet JM, Vaillancourt RE, Kanashiro M, Fady B, Tomita M, Vinson C (2014) Genetic effects of forest management practices: global synthesis and perspectives. For Ecol Manag 333:52-65

Woolsey T (1920) Studies in French forestry. John Wiley \& Sons, New York

Yakovlev IA, Fossdal CG, Johnsen Ø (2010) MicroRNAs, the epigenetic memory and climatic adaptation in Norway spruce. New Phytol 187:1154-1169

Zierhut M (2003) Die Geschichte der Traunsteiner Salinenwälder. Forstl Forschungsber München 194

Zimmermann H (1931) Fichtensamenbeschaffung in Sachsen. Tharandt Forstl Jahrb 82:821-864 